\title{
DISTRIBUSI DAN KELIMPAHAN LARVA IKAN PADA EKOSISTEM MANGROVE DI DESA PASAR BANGGI KABUPATEN REMBANG
}

\section{Distribution and Abundance of Fish Larvae in Mangrove Ecosystem in Pasar Banggi, District Rembang}

\author{
Firtasari Simanullang, Djuwito*), Abdul Ghofar \\ Program Studi Manajemen Sumberdaya Perairan, Jurusan Perikanan \\ Fakultas Perikanan dan Ilmu Kelautan, Universitas Diponegoro \\ J1. Prof. Soedarto, SH, Tembalang, Semarang, Jawa Tengah - 50275, Telp/Fax. +6224 7474698 \\ Email : manullang.firta@gmail.com
}

\begin{abstract}
ABSTRAK
Kabupaten Rembang merupakan salah satu kabupaten yang terletak di pesisir Pantai utara Jawa Tengah yang mempunyai kawasan rehabilitasi mangrove seluas 106,66 ha. Ekositem mangrove di Kabupaten Rembang telah dikelola oleh masyarakat dan LSM setempat untuk dijadikan kawasan wisata dan masyarakat juga membuka lahan tambak yang dapat memberi tekanan bagi fungsi ekologis mangrove. Salah satu dampak yang sangat dikhawatirkan adalah terganggunya habitat vital serta perkembangan larva ikan di area asuhan hutan mangrove. Tujuan penelitian ini adalah mengetahui jenis famili larva ikan, distribusi, kelimpahan, keseragaman, keanekaragaman dan dominasi larva ikan di ekosistem mangrove di Desa Pasar Banggi Kabupaten Rembang. Penelitian ini dilakukan pada bulan April 2016. Pengambilan sampel dilakukan sebanyak tiga kali, dengan interval waktu 1 minggu sekali. Penelitian ini menggunakan metode survei sedangkan pengambilan sampel dilakukan dengan metode stratified sampling. Hasil penelitian didapatkan larva ikan dari tujuh famili, yaitu: Gerreidae, Gobiidae, Clupeidae, Engraulidae, Adrianichtyidae, Megalopidae dan Carangidae. Indeks keanekaragaman berkisar antara 0,087-0,770, dengan nilai tertinggi di wilayah mangrove umur sekitar tiga tahun. Indeks keseragaman berkisar antara 0,062 - 0,555, nilai tertinggi juga pada wilayah umur mangrove sekitar tiga tahun. Nilai indeks dominasi berkisar antara 0,577 - 0,972, dengan nilai tertinggi pada wilayah mangrove berumur lima puluh tahun. Kelimpahan tertinggi larva ikan yang tertangkap pada lokasi penelitian didapat pada wilayah A (wilayah mangrove berumur sekitar lima puluh tahun) adalah sebesar $40 \mathrm{Ind} / \mathrm{m}^{3}$, wilayah B (wilayah mangrove berumur sekitar tujuh tahun) sebesar $22 \mathrm{Ind} / \mathrm{m}^{3}$ dan yang terendah adalah wilayah $\mathrm{C}$ (wilayah mangrove berumur sekitar tiga tahun) sebesar $19 \mathrm{Ind} / \mathrm{m}^{3}$.
\end{abstract}

Kata Kunci : Kelimpahan Larva Ikan; Mangrove; Kabupaten Rembang

\section{ABSTRACT}

Rembang Regency located in the northeastern part of Central Java which has 106.66 ha mangrove rehabilitation area. Mangrove ecosystem in Rembang has been managed by local communities and NGOs for eco-tourism. The local people also have actively cleared mangrove area for artificial ponds that are put an ecological pressure into mangrove ecosystem function. One of the important impact that needs to be concerned is the disruption of vital habitat as well as the development of fish larvae in mangrove area. The purpose of this study was to determine the type of fish larvae families, distribution, abundance, uniformity, diversity and dominance of larval fish in in the mangrove ecosystem of Pasar Banggi, Rembang. The samplings were conducted in April 2016 three times, with intervals one week. The sampling method was done by stratified sampling method. In three times sampling we obtained seven families of fish larvae in the following name: Gerreidae, Gobiidae, Clupeidae, Engraulidae, Adrianichtyidae, Megalopidae and Carangidae. The diversity indices range between 0,087-0,770, with the highest in level in mangrove area with mangrove age of three years. The uniformity index ranges between 0,062 - 0,555, the highest value is also in mangrove area with mangrove age of three years. The dominance index values ranging between 0,577-0,972, with the highest value in the in mangrove area with mangrove age of fifty years. Highest abundance of fish larvae were caught among the sites acquired in the area A ( mangrove area about fifty years) is 40 Ind / $\mathrm{m} 3$, region B ( mangrove area about seven years ) of 22 Ind / $m 3$ and the lowest is the area C (mangrove area about three years old) by 19 Ind $/ \mathrm{m} 3$.

Key Words: Fish Larva Abundance, Mangrove, Rembang District

*) Penulis penanggungjawab

${ }^{\circledR}$ Copyright by Management of Aquatic Resources (MAQUARES) 


\section{PENDAHULUAN}

Sumberdaya larva ikan merupakan salah satu faktor utama dalam menentukan kelestarian sumberdaya hayati perikanan tawar dan perikanan laut. Stadia larva merupakan stadia yang penting bagi perkembangan, khususnya ikan. ketersediaan stadia larva ikan di alam menggambarkan keberadaan ikan dewasa. Larva yang merupakan fase awal dalam kehidupan ikan memiliki penyebaran yang berbeda-beda di setiap ekosistem. Kondisi suatu ekosistem perairan sangat menentukan kelimpahan dan distribusi organisme di dalamnya, namun setiap organisme memiliki kebutuhan yang berbeda untuk hidup sesuai dengan karakteristik kehidupannya.

Secara biologi fase larva akan banyak ditemui di daerah pesisir karena wilayah ini merupakan derah yang potensial untuk larva meneruskan pertumbuhannya, selain karena adanya naluri dari induk ketika memijah, juga dipengaruhi oleh ketersediaan makanan dan ruang. Perairan pantai yang terdiri dari daerah pasang surut, estuari, mangrove, padang lamun, terumbu karang, maupun pantai berpasir merupakan nursery bagi berbagai jenis ikan. Melalui mekanisme hidro-biologi larva ikan yang dilahirkan di daerah lepas pantai akan menuju daerah habitat nursery yang kemudian keberhasilan hidupnya akan berpengaruh terhadap rekrutmen (Amarullah, 2008).

Distribusi dan kelimpahan larva ikan di mangrove merupakan proses rekruitmen alami. Larva ikan bergantung pada fungsi ekologis mangrove untuk melangsungkan kehidupan karena ekosistem mangrove merupakan produsen primer yang mampu menghasilkan sejumlah besar detritus dari serasah daun dan dahan pohon mangrove dimana dari sana tersedia banyak makanan bagi berbagai biota yang mencari makan pada ekosistem mangrove tersebut (Claridge et al., 1986 dalam Redjeki, 2013). Kabupaten Rembang merupakan salah satu kabupaten yang terletak di pesisir Pantai utara Jawa Tengah yang mempunyai kawasan rehabilitasi mangrove seluas 106,66 ha. Kawasan mangrove Desa Pasar Banggi tergolong masih baik namun seiring berjalannya waktu kebutuhan masyarakat akan penggunaan lahan untuk pemukiman, pertambakan dan reklamasi akan mengancam kondisi ekosistem mangrove sebagai tempat penyebaran dan habitat larva ikan. Kondisi tersebut dikhawatirkan akan berpengaruh terhadap distribusi dan kelimpahan biota yang hidup di dalamnya, termasuk sumberdaya larva ikan dimana larva ikan merupakan generasi penerus dalam rekruitmen stok ikan di perairan. Pesisir Pasar Banggi. Tujuan penelitian ini adalah untuk mengetahui jenis famili larva ikan, distribusi, kelimpahan, keseragaman, keanekaragaman dan dominasi larva ikan di ekosistem mangrove desa Pasar Banggi, Rembang.

Sampai dengan saat ini penelitian tentang distribusi dan kelimpahan larva ikan pada berbagai habitat vital di kawasan pantai masih sedikit, khususnya perairan pantai utara Jawa Rembang. Demikian pula informasi tentang keberadaan larva ikan khususnya di perairan Kabupaten Rembang. Informasi ini sangatlah penting untuk mengetahui distribusi larva ikan yang berkaitan dengan daerah asuhannya. Mengingat pentingnya informasi tentang keberadaan larva ikan sebagai dasar dalam usaha pengelolaan sumberdaya perikanan di Kabupaten Rembang, serta belum tersedianya informasi atau data mengenai larva ikan di ekosistem mangrove Desa Pasar Banggi menjadikan penelitian ini perlu dilakukan.

\section{MATERI DAN METODE PENELITIAN}

Materi yang digunakan dalam penelitian ini adalah larva ikan yang tertangkap dari ekosistem mangrove Desa Pasar Banggi, Kabupaten Rembang. Variabel kualitas air yang diukur meliputi suhu , kecerahan, kedalaman, kecepatan arus, salinitasdan derajat keasaman $(\mathrm{pH})$. Alat-alat yang digunakan dalam penelitian ini adalah Scoope net 0,5 mm untuk menjaring larva ikan, terrmometer air raksa untuk mengukur suhu, bola arus untuk mengukur kecepatan arus, secchi disk untuk mengukur kecerahan dan kedalaman, refraktometer untuk mengukur salinitas, $\mathrm{pH}$ paper untuk mengukur $\mathrm{pH}$. Metode yang digunakan dalam penelitian ini adalah metode survei dengan teknik stratified random sampling. Metode stratified random sampling yaitu pengambilan sampel secara terstratifikasi dengan membagi populasi ke dalam kelompok-kelompok yang homogen. Sampling dilakukan dengan tiga kali pengulangan dengan interval waktu pengulangan adalah satu minggu pada bulan April 2016. Lokasi pengambilan sampel dibagi menjadi tiga wilayah yang terdiri dari: wilayah A (mangrove umur 50 tahun), Wilayah B (mangrove umur 7 tahun), Wilayah C (mangrove umur 3 tahun). Pengambilan sampel larva ikan dilakukan dengan menggunakan metode sampling pasif pada setiap wilayah dengan cara mendorong jaring scoope net sejauh $(2 \times 25 \mathrm{~m})$ total sampel larva ikan yang didapatkan adalah 9 sampel. Larva yang sudah dijaring diberi alkohol $70 \%$ yang berfungsi untuk mengawetkan larva ikan. Identifikasi larva menggunakan buku identifikasi larva ikan SEAFDEC (2007), buku identifikasi karangan Okiyama (1988) dan buku Identifikasi karangan Leis dan Brooke (2000). Bentuk scoope net dapat dilihat pada Gambar 1.

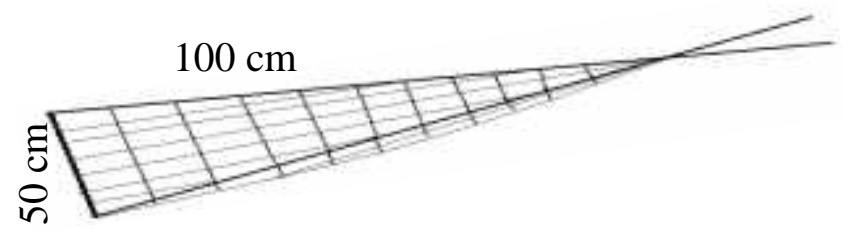

Gambar 1. Alat tangkap Scoope net

${ }^{\circledR}$ Copyright by Management of Aquatic Resources (MAQUARES) 
Rumus kelimpahan larva yang digunakan adalah:

Keterangan :

$$
\mathbf{N}=\frac{\sum \mathbf{n}}{V \operatorname{tsr}}
$$

$\mathrm{N} \quad$ : Kelimpahan larva ikan (ind $/ \mathrm{m}^{3}$ )

$\mathrm{N} \quad$ : Jumlah larva ikan (ind)

Vtsr : Volume air tersaring $\left(\mathrm{m}^{3}\right)$

Vtsr : Jarak dorongan $x$ luas jaring (Odum, 1993 dalam Riswanda, 2015)

Cara memperoleh nilai volume tersaring $\left(\mathrm{m}^{3}\right)$ yaitu:

Keterangan :

\section{Vtsr $=$ Ljaring $x d$}

Vtsr : Volume air tersaring $\left(\mathrm{m}^{3}\right)$

Ljaring : Luas jaring scoope net $\left(\mathrm{m}^{2}\right)$

d : Jarak dorongan (Riswandha, 2015).

Perhitungan Indeks keanekaragaman (H') menurut Shannon dan Weaver (1949) dalam Odum (1993) dengan formula sebagai berikut :

$$
\mathrm{H}^{\prime}=-\sum_{i=1}^{8} p i \cdot \ln . p i^{\prime}
$$

Keterangan :

$H^{\prime}$ : ndeks Keanekaragaman

$\mathrm{Pi}:(\mathrm{ni} / \mathrm{N})$

$\mathrm{N}$ : nilai kepentingan total

ni : nilai kepentingan untuk tiap spesies

Perhitungan Indeks keseragaman berdasarkan persamaan Odum (1993) adalah sebagai berikut:

Keterangan:

$$
e=\frac{H^{\prime}}{H \max }
$$

$H^{\prime} \quad$ : Indeks Shannon

$\mathrm{H} \max : \ln \mathrm{S}$

S : jumlah spesies

Perhitungan Indeks Dominansi menggunakan Indeks Dominansi Simpson (Odum, 1993) dengan rumus sebagai berikut :

$$
\mathrm{C}=\Sigma(n i / N)^{2}
$$

Keterangan:

$\mathrm{C}=$ Indeks dominansi

$\mathrm{n}_{\mathrm{i}}=$ Jumlah individu jenis ke-i

$\mathrm{N}=$ Jumlah total individu

Setelah mendapatkan hasil data primer melalui sampling lapangan dan identifikasi, data akan dianalisis secara deskriptif yang digunakan untuk mendapatkan gambaran umum tentang sebaran data.

\section{HASIL DAN PEMBAHASAN}

A. Hasil

Ekosistem mangrove di Desa Pasar Banggi perlahan semakin membaik seiring dilakukannya program Replant Mangrove untuk menjaga kelestarian ekosistem mangrove. Kondisi mangrove di lokasi penelitian (tabel 2).

Tabel 1. Kondisi Ekositem Mangrove di Lokasi Penelitian

\begin{tabular}{lllll}
\hline No & Parameter & \multicolumn{3}{c}{ Lokasi sampling } \\
\cline { 3 - 5 } & & Wilayah $\mathbf{A}$ & Wilayah B & Wilayah C \\
\hline 1 & Umur & 50 tahun & 7 tahun & 3 tahun \\
2 & Jenis & Rhizopora sp & Rhizopora sp & Rhizopora sp \\
3 & Kanopi & Lebat & Sedang & Belum ada \\
\hline
\end{tabular}

Sumber: Data penelitian, 2016 
Hasil dari Tabel 1 diperoleh dengan cara pengamatan fisik dan pengumpulan informasi dari Ketua Kelompok petani mangrove Desa Pasar Banggi, Rembang.

Variabel yang diukur di lokasi penelitian meliputi suhu air, $\mathrm{pH}$, salinitas, kedalaman dan kecerahan serta kecepatan arus.

Tabel 2. Data Kisaran Parameter Kualitas Air pada Lokasi Penelitian

\begin{tabular}{lccccc}
\hline No & Parameter & Satuan & \multicolumn{3}{c}{ Kisaran Nilai } \\
\cline { 4 - 6 } & & & Wilayah A & Wilayah B & Wilayah C \\
\hline 1. & Suhu & ${ }^{0} \mathrm{C}$ & $28-33$ & $28-33$ & $27-33$ \\
2. & Salinitas & $\% o$ & $27-30$ & $27-30$ & $27-30$ \\
& & & & \\
3. & $\mathrm{pH}$ & & 6 & 6 & 6 \\
4. & Arus & $\mathrm{m} /$ detik & 0 & $0-0.013$ & $0-0.02$ \\
5. & Kecerahan & $\mathrm{Cm}$ & $13.5-35.5$ & $26.5-32$ & $20.5-28.5$ \\
6. & Kedalaman & $\mathrm{Cm}$ & $32-51$ & $53-63$ & $24-43$ \\
\hline
\end{tabular}

Sumber: Data penelitian, 2016

Hasil dari tabel 4 diperoleh dengan pengukuran secara insitu pada saat penelitian. Nilai paremeter kualitas perairan pada lokasi penelitian relatif sama dan tidak menunjukkan perbedaan yang signifikan.

Jumlah total larva ikan yang didapatkan selama tiga kali sampling pada tiga ekosistem mangrove wilayah A, Wilayah B dan Wilayah C dapat dilihat pada Tabel 3.

Tabel 3. Jumlah dan Famili Larva Ikan yang Tertangkap pada Lokasi Penelitian

\begin{tabular}{|c|c|c|c|c|c|c|c|c|c|c|c|c|c|}
\hline \multirow{2}{*}{ Famili } & \multicolumn{4}{|c|}{ Wilayah A } & \multicolumn{3}{|c|}{ Wilayah B } & \multicolumn{4}{|c|}{ Wilayah C } & \multicolumn{2}{|c|}{$\sum$} \\
\hline & $\mathbf{I}$ & II & III & $\sum$ & I & II & III & $\sum$ & $\mathbf{I}$ & II & III & $\sum$ & \\
\hline Clupeidae & - & 2 & - & 2 & - & - & - & - & - & - & - & - & 2 \\
\hline Engraulidae & - & 1 & - & 1 & - & - & - & - & - & - & - & - & 1 \\
\hline Gerreidae & 103 & 492 & 89 & 684 & 97 & 265 & 74 & 436 & 30 & 179 & 17 & 226 & 1346 \\
\hline Gobiidae & - & 1 & 6 & 7 & 7 & 4 & 20 & 31 & - & 13 & 19 & 32 & 70 \\
\hline Megalopidae & - & - & - & - & - & - & 1 & 1 & - & - & 1 & 1 & 2 \\
\hline Carangidae & - & - & - & - & - & - & 1 & 1 & - & - & - & - & 1 \\
\hline Adrianichthyi dae & - & - & - & - & - & 4 & - & 4 & - & 45 & 3 & 48 & 52 \\
\hline Jumlah & & & & 694 & & & & 473 & & & & 307 & 1474 \\
\hline
\end{tabular}

Sumber: Hasill Penelitian, 2016.

Keseluruhan larva ikan yang tertangkap terdiri dari 7 famili. Tabel 3 memperlihatkan bahwa famili Gerreiidae paling banyak ditemukan di setiap lokasi sampling dan diikuti oleh famili Gobiidae. Selama penelitian, famili engraulidae, carangidae dan clupeidae yang ini paling sedikit ditemukan.

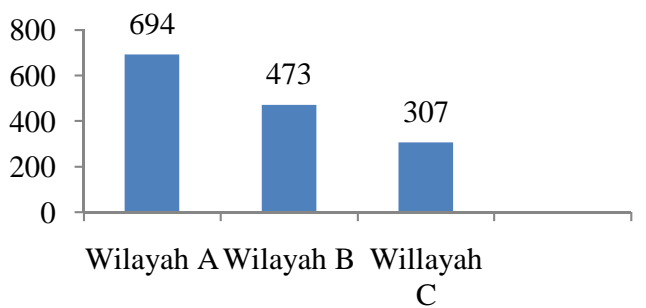

Gambar 1. Jumlah total Larva Ikan pada Wilayah A, Wilayah B dan Wilayah C

Histogram diatas menunjukkan bahwa pada wilayah $\mathrm{C}$ memiliki perolehan larva yang lebih kecil dibandingkan dengan wilayah A dan Wilayah B.

Larva ikan yang tertangkap memiliki sebaran yang berbeda-beda pada lokasi penelitian. Famili Gerreidae dan Gobiidae memiliki sebaran yang cukup luas, dimana dapat ditemukan di seluruh wilayah. Sedangkan sebanyak 5 famili larva ikan hanya ditemukan lokasi tertentu saja. Distribusi sebaran larva ikan pada wilayah penelitian dapat dilihat pada tabel 2. 
Tabel 4. Distribusi kehadiran Larva Ikan di Ekosistem Mangrove Desa Pasar Banggi, Kabupaten Rembang

\begin{tabular}{llrrr}
\hline No & Famili & $\begin{array}{c}\text { Wilayah A } \\
\text { (50 tahun) }\end{array}$ & $\begin{array}{c}\text { Wilayah B } \\
\text { ( 7 tahun) }\end{array}$ & $\begin{array}{c}\text { Wilayah C } \\
\text { (3 tahun) }\end{array}$ \\
\hline 1 & Clupeidae & + & - & - \\
2 & Engraulidae & + & - & - \\
3 & Gerreidae & + & + & + \\
4 & Gobiidae & + & + & + \\
5 & Megalopidae & - & + & + \\
6 & Carangidae & - & + & - \\
7 & Adrianichthyidae & - & + & + \\
\hline
\end{tabular}

Sumber: Hasil Penelitian, 2016

Keterangan : $+=$ Ada,$-=$ Tidak ada

Kelimpahan larva ikan berkisar $8-19 \mathrm{ind} / \mathrm{m}^{3}$ dengan jumlah tertinggi ditemukan pada wilayah A dan terendah pada wilayah C. Dengan asumsi bahwa volume air tersaring dengan jaring scoope net adalah sama, maka perhitungan kelimpahan larva ikan pada saat pengambilan sampel pada saat pasang di tiga wilayah (tabel 5).

Tabel 5. Rata-Rata Kelimpahan Larva Ikan $\left(\mathrm{Ind} / \mathrm{m}^{3}\right)$ pada Lokasi Penelitian

\begin{tabular}{|c|c|c|c|}
\hline \multicolumn{2}{|c|}{ Wilayah Penelitian } & Jumlah larva & Kelimpahan Larva Ikan Ind/m $\mathrm{m}^{3}$ \\
\hline \multirow{3}{*}{ Wilayah A } & Minggu 1 & 103 & 8 \\
\hline & Minggu 2 & 496 & 40 \\
\hline & Minggu 3 & 95 & 7 \\
\hline \multirow[t]{3}{*}{ Wilayah B } & Minggu 1 & 104 & 8 \\
\hline & Minggu 2 & 273 & 22 \\
\hline & Minggu 3 & 96 & 7 \\
\hline \multirow[t]{3}{*}{ Wilayah C } & Minggu 1 & 30 & 2 \\
\hline & Minggu 2 & 237 & 19 \\
\hline & Minggu 3 & 40 & 3 \\
\hline
\end{tabular}

Sumber: Hasil penelitian, 2016

Kelimpahan rata-rata di tiga wilayah penelitian menunjukkan bahwa kelimpahan yang paling tinggi adalah wilayah Adan yang paling rendah adalah di wilayah C. Histogram kelimpahan larva ikan ada pada Gambar 2 .

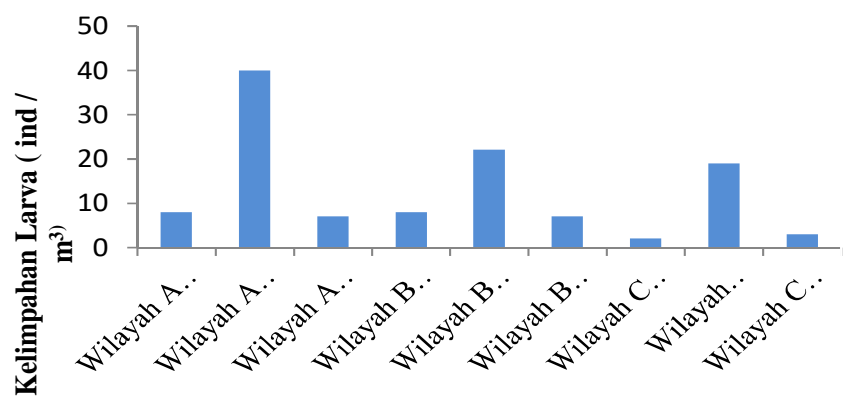

Gambar 2. Kelimpahan Larva Ikan selama penelitian

Nilai Indeks yang dihitung adalah Indeks Keanekaragaman (H'), Indeks Keseragaman (e), dan Indeks Dominasi (D). Untuk hasil perhitungan dapat dilihat pada tabel 6 .

Tabel 6. Indeks Keanekaragaman, Keseragaman dan Dominansi dari 3 lokasi penelitian

\begin{tabular}{ccccc}
\hline No & Lokasi & H' & e & D \\
\hline 1. & Wilayah A & 0,087 & 0,062 & 0,972 \\
2. & Wilayah B & 0,317 & 0,197 & 0,854 \\
3 & Wilayah C & 0,770 & 0.555 & 0,577 \\
\hline
\end{tabular}




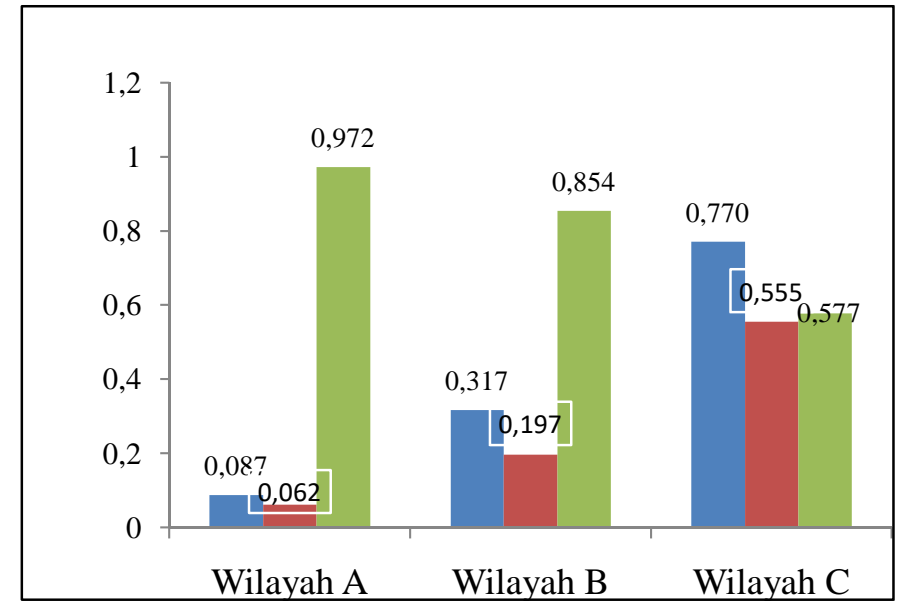

Gambar 3. Indeks Keanekaragaman (H'), Indeks Keseragaman (e), dan Indeks Dominasi Larva Ikan ketiga wilayah Penelitian.

\section{B. Pembahasan}

\section{Kondisi lingkungan perairan}

Suhu perairan pada lokasi penelitian berkisar $27-33^{\circ} \mathrm{C}$. Nilai suhu terendah dijumpai pada minggu kedua wilayah $\mathrm{C}$ sebesar $27^{\circ} \mathrm{C}$. Rendahnya suhu pada minggu kedua diduga karena pada saat sampling pengukuran parameter fisika dilakukan pada pagi hari sebelum matahari menyinari badan perairan. Suhu tertinggi yang didapat adalah $33^{\circ} \mathrm{C}$ hal ini diduga karna pada saat penelitian matahari sudah mulai terik dan pergerakan arus di lokasi penelitian yang tergolong lambat. Suhu ini masih dapat ditolerir oleh biota air khususnya larva ikan.

Hasil penelitian (Anwar, 2008) suhu perairan yang didapatkan selama pengamatan di Teluk Pelabuhan Ratu kisarannya antara $22-29{ }^{\circ} \mathrm{C}$. Suhu yang didapatkan pada saat sampling masih dapat ditolerir oleh larva ikan.

Menurut Effendi (2003) dalam Bahara (2009) suhu suatu badan air dipengaruhi oleh musim, lintang (latitude), ketinggian dari permukaan laut (altitude), waktu dalam hari sirkulasi udara, penutupan awan, dan aliran serta kedalaman badan air. Nilai suhu tertinggi terdapat sampling minggu pertama dan ketiga pada masing-masing wilayah. Sampling pertama dan ketiga dilakukan pukul $11.00 \mathrm{WIB}$, tingginya nilai suhu pada lokasi penelitian diduga akibat pemanasan sinar matahari ke badan perairan.

Nilai suhu yang diperoleh tidak jauh berbeda dengan hasil penelitian Redjeki et al. (2013) suhu perairan di mangrove berada pada kisaran $22,17^{\circ} \mathrm{C}-33,67^{\circ} \mathrm{C}$. Menurut Widodo dan Suadi (2006) dalam Bahara (2009) suhu sangat menentukan laju reaksi kimia (metabolisme) pada semua kehidupan dan pada beberapa jenis ikan suhu sangat menentukan pola perkembangbiakannya. Selain mempengaruhi kehidupan di laut, suhu juga menentukan parameter perairan lainnya seperti jumlah gas terlarut, viskositas air laut, dan densitas, yang juga menentukan distribusi kehidupan di laut.

\section{b. Salinitas}

Nilai salinitas terendah yang diperoleh pada saat sampling adalah $27 \%$, nilai ini diduga dipengaruhi oleh pola gerakan arus, dan nilai tertinggi adalah $30 \%$, tingginya salinitas pada perairan ini diduga karena perairan ini merupakan perairan yang sering dilalui massa air laut terbuka. Menurut Effendi (2003) nilai salinitas yang didapatkan masih dalam batas normal untuk kondisi perairan laut yang berkisar antara 30\%o-40\%. Odum (1993) dalam Bahara (2009) juga menyatakan bahwa salinitas yang cocok berkisar 30 - 40 ppt karena umumnya organisme laut bersifat stenohaline. Hasil penelitian Buwono (2015) di kawasan mangrove, salinitas perairan didapatkan hasil pengukuran yang berbeda pada setiap stasiun yaitu berkisar antara $10 \%$ sampai dengan 35\%.

Menurut Anwar (2008) Salinitas berpengaruh terhadap tingkah laku ikan ataupun distribusi ikan. Hasil pengukuran salinitas yang diperoleh di lapangan dengan keberadaan larva pada masing-masing wilayah menunjukkan kisaran yang sesuai bagi larva, terutama pada saat bermigrasi untuk mengadakan perlindungan dari arus atau gelombang yang kuat.

c. $\mathrm{pH}$ (derajat keasaman)

Nilai $\mathrm{pH}$ yang didapatkan pada saat penelitian memiliki nilai yang konstan yaitu 6. Nilai ini tergolong normal untuk suatu perairan dan masih bisa ditolerir oleh biota dalam perairan. Menurut Chairuddin (1994) dalam Rukmini et al. (2011), kisaran yang optimum untuk pH pada suatu perairan antara 6 - 8.

d. Kedalaman 
Kedalaman perairan pada lokasi sampling berkisar $24-63 \mathrm{~cm}$, kondisi perairan yang dipengaruhi oleh pasang surut membuat nilai kedalaman berbeda-beda. Kedalaman perairan pada wilayah A dan B lebih tinggi dibandingkan wilayah $\mathrm{C}$.

e. Kecerahan

Kecerahan tertinggi pada lokasi sampling berada di wilayah dan $\mathrm{C}$ dan kecerahan terendah terdapat di wilayah A. Rendahnya kecerahan di wilayah A diduga karena wilayah A telah berumur 50 tahun sehingga pada dasar perairan terdapat lebih banyak serasah yang dapat membuat keruhnya perairan dibandingkan dengan wilayah A yang berada dekat dengan pantai yang masih kecil dan belum memiliki kanopi.

f. Kecepatan arus

Kecepatan arus pada saat penelitian berkisar $0-0.02 \mathrm{~m} / \mathrm{s}$, kondisi ini sangat cocok bagi larva ikan yang cenderung berenang lambat di permukaan perairan. Arus dapat mempengaruhi pergerakan dan distribusi larva ikan karena larva ikan yang masih tergolong planktonik. Pada saat sampling arus di wilayah penelitian kecepatan arus sangat rendah hal ini diduga karena kondisi wilayah penelitian yang berada di ekosistem mangrove. Kecepatan arus tertinggi berada di wilayah $\mathrm{C}$, hal ini diduga karena wilayah $\mathrm{C}$ tegakan mangrovenya masih sedikit dibandingkan dengan wilayah A dan B.

\section{Komposisi, kelimpahan dan distribusi larva ikan}

Selama penelitian yang dilakukan pada bulan April 2016 larva ikan yang ditemukan sebanyak 1474 individu dan setelah dilakukan identifikasi sampai tingkat famili didapatkan total keseluruhan larva adalah 7 famili. Larva ikan yang ditemukan diantaranya adalah famili Clupeidae, Engraulidae, Gerreidae, Gobiidae, Adrianichthyidae, Megalopidae dan Carangidae. Pada saat sampling Larva ikan sering kali berkelompok dan berenang lambat di permukaan sehingga mudah ditangkap. Larva ikan yang tertangkap di kawasan penelitian tergolong cukup tinggi. Odum (1996) dalam Pribadi et al. (2013) membuktikan bahwa ekosistem mangrove merupakan daerah ideal bagi beberapa spesies ikan (terutama usia muda) atau dikenal sebagai nursery dan feeding ground.

Jumlah famili larva ikan yang ditemukan ini lebih banyak daripada larva ikan yang ditemukan di mangrove Desa Timbusloko Demak, yakni 5 famili (Riswandha, 2015), namun hasil ini jauh lebih sedikit jika dibandingkan dengan larva yang ditemukan oleh Campbell (2008) di Sian Ka'an Biosphere Reserve, Quintana Roo, Mexico dengan total larva ikan yang tertangkap sebanyak 26 famili.

Menurut Nirarita et al. (1996) dalam Buwono (2015) jenis ikan yang ada di mangrove terdiri dari beberapa kelompok penghuni, diantaranya adalah ikan pengunjung musiman, yaitu ikan-ikan yang menggunakan ekosistem mangrove sebagai tempat memijah dan asuhan, serta tempat perlindungan musiman dari predator. Selain itu, Chong et al. (1990) juga melaporkan bahwa perairan mangrove merupakan tempat mencari makan pada waktu terjadi pasang tinggi bagi ikan-ikan ekonomis maupun non-ekonomis. Komunitas ikan di perairan mangrove didominasi oleh beberapa spesies, meskipun spesies ikan yang tertangkap relatif banyak, dan pada umumnya masih berukuran juvenil.

Gerreidae mendominasi di wilayah A, B dan C dimana famili ini tertangkap sebanyak 1346 individu. famili Gerreidae memiliki jumlah tangkapan yang paling tinggi dan merupakan jenis yang mendominasi di satiap wilayah di duga karena daerah mangrove merupakan daerah asuhan yang cocok bagi famili Gerreidae. Menurut penelitian yang dilakukan oleh Campbell (2008) di mangrove Mexico yang menyatakan bahwa famili yang mendominasi oleh Gerreidae dengan kehadiran mendekati $70 \%$ dari total tangkapan larva. (Tabb dan maning 1961, Carter Et al., 1973, Colby, 1985 dalam Campbell 2008) juga menyatakan bahwa Gerreidae merupakan spesies yang dominan pada jajaran mangrove di Ten Thousand Islands, Florida.

Gobiidae juga ditemukan di semua wilayah pada lokasi penelitian. Hal ini diduga famili Gobiidae memiliki sebaran yang luas. Hal ini didukung oleh Subiyanto et al. (2008) yang menyatakan larva Gobiidae memiliki kemampuan adaptasi yang baik terhadap lingkungan estuaria dan biasanya dominan tertangkap di perairan tersebut. Menurut hasil penelitian yang dilakukan oleh Ooi dan Chong (2011) di muara bakau Kuala Lumpur Malaysia, didapatkan total larva famili Gobiidae yang tertangkap adalah 46.562 individu dan data menunjukkan bahwa famili Gobiidae tertangkap di semua stasiun pada lokasi penelitian.

Selanjutnya larva ikan yang tertangkap adalah famili Adrianichthyidae famili ini juga sering disebut dengan ikan nasi atau Rice fish. Famili ini merupakan jenis ikan yang dapat mentoleransi kadar garam atau salinitas yang tinggi karena ikan ini merupakan spesies air tawar. Pada saat penelitian larva ini ditemukan pada wilayah A dan B. Menurut penelitian yang dilakukan oleh Redjeki (2013) Famili Adrianichthyidae (ordo Beloniformes) yang bersifat benthopelagic dan sering disebut sebagai ikan padi dari habitat asli ikan tersebut, yaitu air tawar. Ikan ini mampu hidup juga di air payau yang sangat dipengaruhi oleh pasang surut.

Larva Megalopidae dan Clupeidae yang didapat pada lokasi penelitian masing-masing 2 individu. Larva Megalopidae merupakan famili melakukan migrasi ke daerah mangrove untuk mecari makan dan menghindar dari predator. Tertangkapnya ikan penghuni daerah mangrove, seperti Megalops dan Valamugil, dikarenakan banyaknya pohon mangrove yang tumbuh di sekitar lokasi penelitian, selanjutnya adanya pengaruh pasang surut sebagai media utama bagi larva dan juvenil untuk bermigrasi ke pantai (McLachlan, 1983 dalam Najamudin et al., 2007). Namun pada saat melakukan sampling di wilayah B dan Wilayah C terdapat beberapa predator 
seperti ular dan ubur-ubur, keberadaan predator dapat mengganggu keberadaan larva di perairan. Anwar (2008) mengemukakan bahwa pada tahap ini tingkat mortalitas tinggi karena peka terhadap predator, ketersediaan makanan dan perubahan lingkungan seperti suhu, salinitas. Dengan demikian tahap ini adalah kondisi yang paling menentukan kelangsungan hidup satu spesies maupun populasi ikan tersebut.

Famili Engraulidae dan Carangidae merupakan famili yang paling jarang ditemui pada saat penelitian. Kedua famili ini hanya ditemukan pada wilayah tertentu saja. Famili Engraulidae hanya tertangkap 1 individu pada saat penelitian. Jumlah ini jauh lebih sedikit dibandingkan dengan famili Engraulidae yang tertangkap di wilayah muara mangrove Marudu bay, Sabah, Malaysia (Rezagholinejad et al., 2016) dengan total larva famili Engraulidae yang tertangkap adalah 555 individu. hasil tangkapan famili Engraulidae dan Carangidae yang sangat kecil dan merupakan famili yang paling jarang ditemui pada wilayah penelitian diduga karena setiap ikan memiliki waktu yang berbeda-beda untuk memijah, sehingga pada saat sampling tidak ditemukan larva ikan dalam jumlah yang banyak. Ooi dan Chong (2011) mengatakan bahwa rata-rata kepadatan famili Engraulid di perairan lepas pantai lebih tertinggi pada agustus 2002. Larva engraulid berada dalam fase preflexion pada baik di mangrove maupun di perairan lepas pantai. Pada perairan lepas pantai lebih dari $70 \%$ dari total larva engraulid konsisten berada pada fase preflexion dari bulan Mei hingga Desember 2002 dengan kelimpahan tertinggi berda pada bulan september 2002 (99\%). Data menunjukkan bahwa pemijahan engraulid kemungkinan besar terjadi dari bulan Mei hingga September.

Famili Carangidae yang hanya tertangkap pada wilayah B merupakan jenis ikan karang, hal ini dimungkinkan karena pada lokasi penelitian berada di dekat pantai dan diduga terbawa arus sampai ke daerah mangrove. Seperti dinyatakan Leis (1986) dalam Najamuddin (2007) bahwa larva dan juvenil ikan karang secara reguler didapatkan di daerah pantai yang letaknya berdekatan dengan karang. Famili ini juga ditemukan oleh Ooi dan Chong (2011) sebanyak 46 individu di mangrove estuari Kuala lumpur, Malaysia. Ooi dan Chong (2011) juga menambahkan bahwa sebagian besar famili carangidae pada tahap preflexion berada di area perairan lepas pantai.

Sebaran kehadiran larva dan juvenil ikan yang bersifat terputus-putus diduga akibat pemijahan parsial atau bertahap sehingga kehadirannya di wilayah mangrove juga bersifat periodik atau musiman. Larva ikan yang memiliki sebaran kehadiran yang kecil diduga akibat adanya larva ikan yang sedang melakukan migrasi di wilayah tersebut yang secara tidak sengaja tertangkap selama periode sampling dan diduga terjadi karena masa puncak pemijahan ikan yang berbeda beda sehingga larva ikan yang ditemukan tergolong sedikit. Patty (2008) dalam Pribadi et al. (2013) mengemukakan bahwa distribusi vertikal ikan di perairan pantai sekitar mangrove, ditemukan bervariasi secara temporal. Pribadi et al. (2013) juga menambahkan bahwa pada sore dan pagi hari, ikan banyak dijumpai pada lapisan permukaan, sedangkan pada siang hari cenderung berada di lapisan lebih dalam. Hal ini disebabkan faktor suhu yang mempengaruhi tingkah laku ikan, dimana mereka cenderung mencari daerah yang cocok seperti suhu yang relatif lebih rendah. Peranan arus pasang surut juga terlihat dalam membawa ikan untuk mencapai sumber makanan (mangrove) dan membawa serasah mangrove ke perairan sekitar sehingga komunitas ikan yang dijumpai di sana cukup banyak dan beragam.

Menurut Sentosa dan Anggraeni (2010) kehadiran spesies ikan yang bersifat terputus-putus tersebut menunjukkan bahwa pemijahannya bersifat parsial atau bertahap sehingga kehadirannya di muara tidak bersifat kontiniu. Hal tersebut terlihat dari kehadiran spesies ikan pada bulan-bulan tertentu saja sehingga dapat dikatakan keberadaannya bersifat musiman. Sulistiono et al. (2008) juga mengungkapkan bahwa spesies yang berbeda mempunyai waktu reproduksi yang berlainan sehingga larva berada di perairan pada waktu berbeda dalam setahun sehingga berpengaruh terhadap asosiasi yang terjadi.

Menurut Baskoro et al. (2004) Migrasi dan distribusi suatu jenis ikan merupakan hal penting yang harus diketahui, karena dengan mengetahui pola migrasi dan distribusi suatu jenis ikan maka akan diketahui batasbatas daerah dimana stok atau sub populasi dari suatu jenis ikan hidup. Menurut Bahara (2009) ikan mengadakan migrasi dalam rangka : (1) pemijahan; (2) mencari makanan; dan (3) mencari daerah yang cocok untuk kelangsungan hidupnya, tidak terlepas dari beberapa faktor eksternal dan internal dari suatu jenis ikan. Faktor eksternal berupa faktor lingkungan yang secara langsung atau tidak langsung memegang peranan dalam migrasi ikan. Ikan dapat merubah pola migrasi yang telah ada ke pola migrasi yang lain, dengan bergantung pada kondisi lingkungan yang mempengaruhinya. Selama tahap-tahap kehidupan ikan dalam bermigrasi, ikan yang hidup soliter dapat melakukan pola migrasi yang berbeda pada satu waktu.

Kelimpahan larva ikan seperti yang tertera di tabel 6 dimana wilayah A memiliki kelimpahan yang tertinggi sebesar $40 \mathrm{ind} / \mathrm{m}^{3}$, wilayah A merupakan daerah mangrove yang memiliki kanopi yang lebat dan terdapat serasahn memungkinkan daerah ini memiliki kelimpahan larva ikan yang tinggi, larva ikan selain mencari daerah asuhan di sekitar mangrove juga untuk mencari makanan yang berasal dari serasah mangrove. Berbeda dengan wilayah $\mathrm{C}$ yang masih kecil dan tidak terdapat kanopi kelimpahan pada daerah $\mathrm{C}$ hanya $2 \mathrm{ind} / \mathrm{m}^{3}$. Rendahnya kelimpahan di wilayah $\mathrm{C}$ juga diduga disebabkan karena kehadiran predator seperti ular dan ubur-ubur pada saat sampling. Kelimpahan di wilayah penelitian jauh lebih sedikit dibandingkan dengan penelitian Bahara (2009) Kelimpahan larva ikan yang banyak tertangkap menurut perhitungan setiap bulannya dari 8 stasiun adalah pada bulan Juli, yaitu 608 individu $/ \mathrm{m}^{3}$ dan hasil tangkapan terendah adalah pada bulan Mei yaitu $439 \mathrm{individu} / \mathrm{m}^{3}$.

(C) Copyright by Management of Aquatic Resources (MAQUARES) 


\section{Struktur komunitas larva ikan}

Hasil analisis Indeks Keanekaragaman (H'), Indeks Keseragaman (e), dan Indeks Dominansi (D) larva ikan menunjukkan nilai yang berfluktuatif (tabel 8). Pada setiap wilayah nilai indeks keanekaragaman dari hasil analisis setiap wilayah menunjukkan keanekaragaman populasi yang rendah. Hal ini diduga terjadi karena masa pemijahan ikan berbeda-beda sehingga jumlah sebaran larva di dalam perairan sedikit. Odum (1993) dalam Redjeki (2013) mengemukakan bahwa suatu kondisi dimana mempunyai nilai Indeks Keseragaman kurang dari 1 (H'< 1) maka lokasi tersebut berada dalam kategori yang mempunyai tingkat keanekaragman rendah. Kelimpahan yang tidak merata pada semua famili ikan yang ditemukan, menjadikan nilai keanekaragaman tidak tinggi.

Indeks keseragaman (e) dianalisis untuk melihat seberapa besar kesamaan sebaran individu di dalam suatu komunitas atau populasi pada lokasi penelitian (Odum, 1971 dalam Riswandha 2015). Hasil analisis menunjukkan bahwa pada setiap wilayah di lokasi penelitian memiliki nilai yang berbeda-beda. Nilai yang terendah berada pada wilayah A hal ini terjadi karena pada wilayah A terdapat satu jenis famili yang lebih mendominasi sehingga nilai keanekaragaman pada wilayah A sangat rendah, selain itu selama melakukan sampling kelimpahan larva yang tidak merata pada setiap stasiun juga menyebabkan nilai indeks keanekaragaman menjadi rendah. Pada wilayah A hanya terdapat 4 jenis famili larva yang tertangkap. Menurut kriteria Ambarita (2009) dalam Riswandha (2015), bahwa nilai indeks keseragaman pengamatan dibagi menjadi pada kriteria dengan kondisi labil dan stabil. Berdasarkan nilai indeks keanekaragaman yang didapatkan pada setiap wilayah maka ekosistem dikatakan labil karena nilai indek keseragaman wilayah penelitian berkisar 0,062 $-0,555$.

Hasil analisis indeks dominansi antar wilayah pada lokasi penelitian diperoleh nilainya tergolong tinggi yaitu berkisar 0,577 - 0,972, nilai ini menunjukkan bahwa pada lokasi penelitian terdapat jenis yang mendominasi pada suatu ekosistem. Dhahiyat et al. (2009) dalam Riswandha (2015) menambahkan bila dalam suatu struktur komunitas biota yang diamati terdapat spesies yang mendominasi, maka hal ini menunjukkan bahwa kondisi struktur komunitas berada dalam keadaan labil atau sedang terjadi tekanan ekologis. Sedangkan yang terjadi saat penelitian berbanding terbalik, yaitu tidak ada yang mendominasi walaupun jika dilihat dari nilai indeks keseragaman, maka ekosistem tersebut masih tergolong labil. Menurut Redjeki et al. (2013) Semakin kecil nilai e (Indeks Keseragaman), maka semakin kecil pula keseragaman populasi. Jadi apabila penyebaran jumlah individu setiap jenis tidak sama dan ada kecenderungan satu spesies mendominasi.

\section{KESIMPULAN}

Berdasarkan hasil penelitian yang telah dilakukan, dapat disimpulkan bahwa :

1. Larva ikan yang tertangkap di ekosistem mangrove Desa Pasar Banggi terdiri dari 7 famili dengan dengan famili yang dominan adalah Gerreidae, Gobiidae, Adrianichthyidae, Clupeidae, Megalopidae, Engraulidae dan Carangidae.

2. Distribusi kehadiran larva ikan pada semua wilayah tidak seluruhnya merata. Famili Gerreidae dan Gobiidae ditemukan memiliki sebaran yang cukup luas untuk Wilayah A, wilayah B dan Wilayah C, sedangkan famili Adrianichthyidae, Clupeidae, Megalopidae, Engraulidae, dan Carangidae tidak menyeluruh ditemukan pada semua wilayah.

3. Kelimpahan tertinggi larva ikan yang tertangkap pada lokasi penelitian didapat pada wilayah A adalah sebesar $40 \mathrm{Ind} / \mathrm{m}^{3}$, wilayah B sebesar $22 \mathrm{Ind} / \mathrm{m}^{3}$ dan wilayah C sebesar $19 \mathrm{Ind} / \mathrm{m}^{3}$.

\section{UCAPAN TERIMA KASIH}

Penulis mengucapkan terima kasih kepada Tuhan Yang Maha Esa yang telah memberikan berkat dan kasihnya-Nya sehingga penulis dapat menyelesaikan penelitian ini. Terima kasih kepada Bapak Suyadi, bapak Sahal selaku ketua LSM, Desa Pasar Banggi, Kabupaten Rembang. Terima kasih kepada Drs. Ign. Boedi Hendrarto, M.Sc, Ph.D, Ir. Anhar Solichin M.Si, dan Dr. Ir. Pujiono W. Purnomo, MS, untuk saran dan masukannya di dalam penyusunan penulisan ini. Serta kepada seluruh pihak yang membantu selama penelitian ini.

\section{DAFTAR PUSTAKA}

Amarullah, M.H. 2008. Hidro-Biologi Larva Ikan dalam Proses Rekruitmen,. Jurnal Hidrosfir indonesia., 3(2): 75-80 hlm.

Bahara, M.A. 2009. Distribusi Spasial dan Temporal Larva Ikan di Perairan Pulau Abang Galang Baru Batam Provinsi Kepulauan Riau. [Tesis]. Sekolah Pascasarjana Institut Pertanian Bogor, Bogor, 84 hlm.

Baskoro, Mulyono S. dan A. Effendy. 2004. Tingkah Laku Ikan Hubungannya dengan Metode Pengoperasian Alat Tangkap Ikan. [Tesis]. Departemen Pemanfaatan Sumberdaya Perikanan. Fakultas Perikanan dan Ilmu Kelautan. Institut Pertanian Bogor, Bogor, 56 hlm. 
Buwono, Y.R. 2015. Potensi Fauna Akuatik Ekosistem Hutan Mangrove di Kawasan Teluk Pangpang Kabupaten Banyuwangi. [Tesis]. Program Pascasarjana Universitas Udayana Denpasar, Denpasar, 85 hlm.

Campbell, M. 2008. Occurrence of Larval and Juvenile Fish in Mangrove Habitats in the Sian Ka'an Biosphere Reserve, Quintana Roo, Mexico. Gulf and Carribean Research., 20: 81-85 hlm.

Najamuddin, A., Sulistiono dan Subiyanto. 2007. Studi Komposisi Jenis dan Kelimpahan Larva dan Juvenil Ikan di Pantai Tanjung Mangkok, Kalimantan Selatan. Jurnal Ilmu-ilmu Perairan dan Perikanan Indonesia., 2: 23-27 hlm.

Ooi, A.L. and V.C. Chong. 2011. Larval Fish Assemblages in a Tropical Mangrove Estuary and Adjacent Coastal Waters: Offshore-In Shore Flux of Marine and Estuarine Species. Continental Shelf Research., 31: 1599-1610 p.

Pribadi, H., Endrawati dan I. Pratikto. 2013. Komunitas Ikan di Perairan Kawasan Pulau Parang, Kepulauan Karimunjawa, Jepara. Jurnal Ilmu Kelautan., 18(1): 45-53 hlm.

Redjeki, S. 2013. Komposisi dan Kelimpahan Ikan di Ekosistem Mangrove di Kedungmalang, Jepara. Jurnal Ilmu Kelautan., 18(1): 54-60

Redjeki, S., Irwani dan F. M. Hisyam, 2013. Struktur Komunitas Ikan pada Ekosistem Mangrove di Desa Bedono Sayung, Demak, Buletin Oseanografi Marina., 2: 78 - 86.

Rezagholinejad, S., A. Arshad, N. Amin S.M., and Ehteshami F. 2016. The Influence of Environmental Parameters on Fish Larval Distribution and Abundance in the Mangrove Estuarine Area of Marudu Bay, Sabah, Malaysia. Journal of Survey in Fisheries Sciences., 2(2): 67-68 p.

Riswandha, N.S. 2015. Struktur Komunitas Larva Ikan pada Ekosistem Mangrove dengan Umur Vegetasi yang Berbeda di Desa Timbulsloko, Demak. [Skripsi]. Fakultas Perikanan dan Ilmu Kelautan, Universitas Diponegoro Semarang, Semarang, 164-173 hlm.

Sentosa, A.A. dan R.D. Anggraeni. 2010. Sebaran Ukuran dan Kehadiran Larva dan Juvenil Ikan di Muara Sungai Bogowonto Kabupaten Kulon Progo Dalam: Seminar Nasional Biologi di Yogyakarta Tanggal 24-25 September 2010, 243 - 253 hlm.

Soeroyo, 1992. Sifat, Fungsi, dan Peranan Hutan Mangrove. Pusat Penelitian dan Pengembangan OseanologiLIPI, Jakarta, 15 hlm.

Subiyanto, Ruswahyuni, dan D. G. Cahyono. 2008. Komposisi dan Distribusi Larva Ikan Pelagis di Estuaria Pelawangan Timur, Segara Anakan, Cilacap. Jurnal Saintek Perikanan., 4(1): 62 - 68. 